\title{
$\Psi$
}

\section{DINAMIKA PERILAKU “NAKAL" ANAK BERAMBUT GIMBAL DI DATARAN TINGGI DIENG}

\begin{abstract}
ABSTRAK Penelitian ini bertujuan untuk menjelaskan fenomena perilaku "nakal" yang melekat pada anak berambut gimbal (titisan Ki Kolodete) di dataran tinggi dieng Jawa Tengah. Tradisi memotong rambut gimbal kerap kali juga dipandang sebagai menghilangkan kenalakan pada anak yang berambul gimbal. Penelitian ini menggunakan pendekatan kualitatif dengan metode studi kasus yang melibatkan 4 orang anak berambut gimbal sebagai respoden yang dipilih berdasarkan purposive sampling dan 28 informan. Teknik analisis data yang digunakan adalah teknik analisis dan interpretasi data Stevick-Colaizzi-Keen yang telah dimodifikasi oleh Moustakas. Adapun teknik verifikasi data dilakukan dengan menggunakan triangulasi data dan member checking. Hasil temuan penelitian menyatakan bahwa secara umum penyebab munculnya perilaku "nakal" anak berambut gimbal ini diklasifikasikan menjadi dua faktor, yakni faktor internal dan faktor eksternal. Faktor internal terdiri dari kondisi kesehatan fisik dan usia anak berambut gimbal. Adapun faktor eksternal terdiri dari pengasuhan, sugesti kolektif, kepercayaan tentang anak rambut gimbal, persepsi terhadap kepercayaan tentang anak berambut gimbal dan latar belakang demografi. Adapun penyebab perubahan perilaku anak berambut gimbal pasca ruwatan juga dikarenakan oleh dua faktor utama yang bersifat interdependen, yakni faktor internal dan faktor eksternal. Faktor internal adalah usia dan kondisi kesehatan. Adapun faktor eksternal terdiri dari kepercayaan terhadap tradisi ruwatan, prosesi ruwatan, pengasuhan dan latar belakang demografi.
\end{abstract}

\author{
Puspa Ayu Damayanti \\ Alumnus Program Pascasarjana Psikologi \\ Universitas Gadjah Mada Yogyakarta \\ email:ayu2012@gmail.com
}

PSIKOISLAMIKA, Jurnal Psikologi Islam (JPI) Copyrigth ( 2011 Lembaga Penelitian Pengembangan Psikologi dan Keislaman (LP3K). Vol 8No_2_Januari 2011 165-190 


\section{Muqadimah}

Di dataran tinggi Dieng, yakni sebuah kawasan pegunungan yang terletak di Kabupaten Wonosobo dan Banjarnegara, Provinsi Jawa Tengah, lahir sekelompok Anak Bajang, sebutan bagi anakanak berambut gimbal. Anak berambut gimbal adalah mereka yang memiliki rambut berjenis gimbal. Dalam bahasa Jawa, gimbal berarti menggumpal (Purwadi, 2003). Rambut gimbal adalah rambut yang menggumpal. Bukan tidak pernah dirawat, bukan pula sengaja dibuat gimbal, rambut anak-anak ini tumbuh secara alami. Anak berambut gimbal lahir dalam keadaan normal sebagaimana anak-anak lainnya, namun pada usia tertentu, anak yang "terpilih", biasanya akan mengalami demam tinggi, dan rambutnya berubah menjadi gimbal (Bestarini, 2009; Rambey, 2009; Wibowo, 1969; Yulianto, 2009).

Sehari-harinya, anak berambut gimbal menampakkan perilaku yang sedikit berbeda dengan anak-anak lain seusianya. Anak berambut gimbal cenderung dinilai sebagai anak yang "nakal". Sebutan "nakal" yang dilekatkan pada anak berambut gimbal merupakan istilah bagi perilaku mereka yang kerap menangis hebat, meronta, merengek dan mengamuk dalam waktu yang cukup lama ketika apa yang diinginkannya tidak segera dipenuhi. Ketika anak berambut gimbal menginginkan sesuatu, maka pada saat itu pula apa yang diinginkannya harus segera dipenuhi. Jika terlambat sesaat saja, maka anak berambut gimbal akan menangis dan mengamuk sekuat tenaganya. Tidak hanya itu, anak berambut gimbal pun tidak segansegan melakukan serangan-serangan berupa pukulan, tendangan, dan perilaku-perilaku agresif lainnya untuk mendapatkan apa yang mereka inginkan. Dalam kasus tertentu, anak berambut gimbal akan menyakiti dirinya sendiri hanya agar keinginannya segera dipenuhi. Tidak ada frekuensi stabil yang ditunjukkan dari perilaku-perilaku tersebut setiap harinya. Keinginan yang tidak terpenuhi merupakan stimulus yang kerap memprovokasi perilaku-perilaku yang tidak diharapkan (hasil wawancara dan observasi pada tanggal 12 Desember 2009 dan 26 Juni 2010).

Masyarakat setempat menilai bahwa anak berambut gimbal begitu mudah terbawa emosi. Pada beberapa kasus, ketika tersentuh oleh teman sebayanya, mereka marah dan melakukan seranganserangan tertentu. Jika mendapat teguran oleh orangtua atau orang dewasa lainnya, mereka akan melawan. Anak berambut gimbal sering berperilaku seenaknya sendiri dan suka memberontak. Oleh karena 
itu, anak berambut gimbal kerap dijauhi oleh teman sebayanya karena perilaku-perilaku yang tidak dapat ditoleransi. Akibatnya, meskipun tidak terjadi pada setiap anak berambut gimbal, akan tetapi sebagian besar anak berambut gimbal hanya menjalin hubungan dengan orangorang terdekat terutama orangtua dan keluarga (hasil wawancara dan observasi pada tanggal 12 Desember 2009 dan 26 Juni 2010).

Kondisi-kondisi inilah yang pada akhirnya membuat anak berambut gimbal dinilai berbeda dengan anak-anak lain seusianya. Perilaku-perilaku tersebut, meskipun belum dapat digolongkan sebagai gangguan atau patologis, namun cukup membuat orangtua kewalahan dalam menghadapinya. Meski demikian, sebagaimana yang disampaikan masyarakat setempat bahwa perilaku-perilaku itu akan berhenti ketika anak berambut gimbal memotong rambutnya (hasil wawancara dan observasi pada tanggal 12 Desember 2009 dan 26 Juni 2010).

Sifat "nakal" sebagaimana yang dijelaskan oleh masyarakat setempat mengenai perilaku anak berambut gimbal pada hakikatnya merupakan hal biasa yang selalu melekat pada diri anak seusia mereka. Anak berambut gimbal adalah anak-anak yang berada pada masa kanak-kanak awal, yakni periode pada saat anak berusia dua sampai enam tahun (Hurlock, 1980).

\section{Kerangka Kerja Teoritik}

Awal masa kanak-kanak seringkali dianggap sebagai usia yang mengundang masalah atau usia sulit. Pada masa ini, orangtua tidak lagi disibukkan oleh masalah-masalah perawatan secara fisik sebagaimana ketika masih bayi, namun masa kanak-kanak sering memunculkan berbagai masalah perilaku yang lebih menyulitkan. Hal ini disebabkan karena anak-anak pada masa ini sedang dalam proses pengembangan kepribadian yang unik dan menuntut kebebasan yang pada umumnya tidak selalu mereka dapatkan. Selain itu, selama awal masa kanak-kanak, emosi menjadi sangat kuat. Masa kanak-kanak awal merupakan saat ketidakseimbangan karena anak-anak keluar dari fokus yang menyebabkan ia mudah terbawa ledakan-ledakan emosional sehingga sulit dibimbing dan diarahkan (Hurlock, 1980).

Selain masalah usia, beberapa hasil penelitian melaporkan terdapat berbagai faktor̂ryang mienyebabkan munculnya masalah- 
masalah perilaku pada anak, di antaranya adalah faktor demografis (McCoy, Frick, Loney, \& Ellis, 1999), kontekstual seperti status sosial ekonomi, tetangga, lingkungan tempat tinggal dan teman sebaya (Conger dkk., 1992; Ellis \& Zarbatany, 2007; Georgiades, Boyle, \& Duku, 2007; McCoy, dkk., 1999; Mrug \& Windle, 2009), orangtua (Nagin \& Tremblay, 1999; Shaw, Gilliom, Ingoldsby, \& Nagin, 2003; Tremblay dkk., 2004), termasuk di dalamnya masalah psikopatologi orangtua (Cummings \& Davies, 1994), status dan konflik perkawinan (Buehler \& Gerard, 2002; Emery, Waldron, Kitzmann, \& Aaron, 1999; Jouriles, Pfiffner, \& O'Leary, 1988; Kaczynski, Lindahl, Malik, \& Laurenceau, 2006), pengasuhan (Curtner-Smith, 2000; Flouri \& Buchanan, 2003; Frick, Christian, \& Wootton, 1999; Kaczynski dkk, 2006; McCoy dkk., 1999; Miller, A. Cowan, P. Cowan, Hetherington, \& Clingempeel, 1993; O'Leary \& Vidair, 2005), dan anak itu sendiri berkaitan dengan regulasi emosi \& kurangnya perhatian (Hill, Degnan, Calkins, \& Keane, 2006).

Timbulnya berbagai masalah perilaku pada anak tidak hanya disebabkan oleh satu faktor penyebab saja, akan tetapi dimungkinkan disebabkan oleh berbagai hal yang sangat kompleks dan saling berkaitan antara penyebab yang satu dengan penyebab yang lain. Sebagaimana yang dilaporkan dalam penelitian Buehler \& Gerard (2002); O'Leary \& Vidair (2005) bahwa masalah perilaku yang muncul pada anak diawali oleh masalah penyesuaian dalam perkawinan yang pada akhirnya merambah pada ketidaksepakatan dalam membesarkan anak yang berimplikasi terhadap pendisiplinan yang bersifat over reaktif dan memunculkan masalah perilaku pada anak. Hal serupa juga dilaporkan oleh McCoy dkk. (1999) dalam penelitiannya yang menunjukkah bahwa pengasuhan dapat menjadi penghubung antara status sosial ekonomi dan etnis terhadap munculnya masalah perilaku anak. Hasil penelitian-penelitian tersebut, menunjukkan bahwa perilaku seseorang disebabkan oleh berbagai faktor yang saling pengaruh mempengaruhi dan bersifat sangat kompleks.

Perilaku-perilaku eksternal di masa kanak-kanak awal seperti merengek, melawan dan agresi ini masih dikategorikan sebagai perilaku yang normal dalam fase perkembangan dan berlaku umum pada seluruh periode awal masa kanak-kanak, akan tetapi di wilayah Dataran Tinggi Dieng hanya anak-anak berambut gimballah yang menunjukkan perilaku-periakut tersebut secara berlebihan. Anak- 
anak yang tidak berambut gimbal juga melakukan hal yang sama, namun demikian masyarakat mengatakan bahwa kenakalan yang mereka tunjukkan masih dalam tingkatan "kira-kira" atau wajar dan tidak berlebihan sebagaimana yang dilakukan oleh anak-anak berambut gimbal. Jika seorang anak biasa menginginkan sesuatu dan belum dapat dipenuhi saat itu, mereka tidak menangis hebat, merengek atau bahkan mengamuk sebagaimana yang terjadi pada anak berambut gimbal (hasil wawancara dan observasi pada tanggal 12 Desember 2009 dan 26 Juni 2010).

Masyarakat setempat berkeyakinan bahwa "kenakalan" tersebut merupakan akibat dari rambut gimbal yang tumbuh di kepala mereka sebagai ciri-ciri keturunan Ki Kolodete, orang yang diyakini sebagai pembuka pertama daerah Dieng dan sekitarnya. Ketika rambut gimbal tersebut dipotong, maka perilaku-perilaku yang dianggap berlebihan pun akan hilang bersamaan dengan rambut yang terpotong. Dengan kata lain, berbagai perilaku negatif yang pada awalnya begitu melekat pada anak berambut gimbal akan berubah setelah rambut gimbalnya dipotong (hasil wawancara dan observasi pada tanggal 12 Desember 2009 dan 26 Juni 2010).

Sekilas tampak bahwa rambut gimbal yang tumbuh di kepala anak-anak tersebut menjadi faktor utama penyebab munculnya perilaku "nakal" pada mereka, namun apakah perilaku-perilaku itu memang benar disebabkan oleh rambut gimbalnya saja sebagaimana yang dipercayai masyarakat setempat ataukah disebabkan oleh faktor lainnya? Berdasarkan latar belakang ini, peneliti tertarik untuk mengkajinya secara komprehensif. Mengapa anak berambut gimbal kerap menunjukkan perilaku "nakal"? Bagaimana perubahan perilaku tersebut terjadi pasca pemotongan rambut gimbalnya?

\section{Metode}

Penelitian ini akan dilakukan di Desa Karang Tengah, Kecamatan Batur Kabupaten Banjarnegara, Provinsi Jawa Tengah. Berdasarkan latar belakang permasalahan, maka peneliti menggunakan pendekatan kualitatif dengan metode studi kasus. Penelitian ini akan melibatkan 4 orang anak berambut gimbal sebagai respoden yang dipilih berdasarkan purposive sampling dan 28 informan yang terdiri informan pelaku seperti orangtua, paman, bibi, kakek nenek, dan informan tahu seperti tetangga, guru dan pemangku adat dataran tinggi Dieng. 
Sesuai dengan sifat penelitian kualitatif yang terbuka dan luwes, teknik pengumpulan data dalam penelitian kualitatif sangat beragam disesuaikan dengan masalah, tujuan penelitian, serta sifat objek yang diteliti. Dalam penelitian ini, peneliti menggunakan wawancara dan observasi. Sedangkan teknik analisis data yang digunakan adalah teknik analisis dan interpretasi data StevickColaizzi-Keen yang telah dimodifikasi oleh Moustakas. Adapun teknik verifikasi data dilakukan dengan menggunakan triangulasi data dan member checking.

\section{Hasil}

\section{Penyebab Munculnya Perilaku Nakal Anak Berambut Gimbal}

Secara umum anak berambut gimbal memiliki satu kesamaan perilaku, yakni perilaku "nakal", suatu perilaku di mana anak suka meminta sesuatu yang harus segera dipenuhi saat itu juga. Ketika permintaan itu belum dipenuhi, maka anak berambut gimbal akan menangis dan mengamuk hingga mereka mendapatkan apa yang mereka inginkan.

Perilaku "nakal" ini secara psikologis dikenal dengan istilah temper tantrum. Temper tantrum merupakan ledakan emosi yang sangat kuat, disertai rasa marah, serangan agresif, menangis, menjeritjerit, menghentak-hentakkan kedua kaki dan tangan ke lantai atau tanah (Chaplin, 2006). Singkatnya, temper tantrum adalah luapan emosi yang meledak-ledak dan tidak terkontrol (Tasmin, 2002) yang biasanya berhenti saat anak mendapatkan apa yang diinginkan (Tavris, 1989).

Berdasarkanhasilpenelitian, secaraumumpenyebabmunculnya perilaku "nakal" anak berambut gimbal ini diklasifikasikan menjadi 2 faktor, yakni faktor internal dan faktor eksternal. Faktor internal terdiri dari kondisi kesehatan fisik dan usia anak berambut gimbal. Adapun faktor eksternal terdiri dari pengasuhan, sugesti kolektif, kepercayaan tentang anak rambut gimbal, persepsi terhadap kepercayaan tentang anak berambut gimbal dan latar belakang demografi.

Perilaku "nakal" mulai ditunjukkan anak sejak munculnya rambut gimbal di mana pada saat itu anak mulai sakit-sakitan. Keempat subjek mulai berambut gimbal pada akhir masa bayi

\section{Created with}

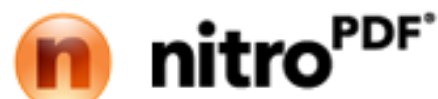


menuju masa kanak-kanak awal. Tumbuhnya rambut gimbal selalu ditandai dengan sakit seperti demam, batuk dan sariawan dalam waktu yang tidak menentu. Akibat sakit yang dialami ketika gimbal mulai tumbuh, anak-anak berambut gimbal ini kerap menangis.

Semakin lama, semakin banyak rambut gimbal yang tumbuh dan semakin sering pula anak mengalami sakit. Selain itu, bentuk rambut gimbal yang menggumpal, menyebabkan kepala anak terasa lebih berat dan tidak jarang mereka diejek oleh teman sebayanya. Sebagaimana yang diungkapkan oleh Hurlock (1978) bahwa apapun penyebab dari munculnya sakit yang diderita anak, baik fisiologis maupun psikologis, akan mempengaruhi perkembangan, perilaku, pembentukan kepribadian dan sikap anak.

Hart, Box and Jenkins (1984) melakukan penelitian untuk mengetahui hubungan antara kesehatan dan perilaku. Hasil penelitian tersebut menyimpulkan bahwa kesehatan dan masalah perilaku seringkali muncul secara berdampingan. Lebih detailnya Hurlock (1978) menerangkan bahwa kondisi kesehatan yang tidak stabil ini pada hakikatnya turut mempengaruhi emosi anak. Hurlock (1978) menjelaskan bahwa kesehatan yang baik akan mendorong emosi yang menyenangkan menjadi dominan, sedangkan kesehatan yang buruk menyebabkan emosi yang tidak menyenangkan menjadi dominan. Anak berambut gimbal kerap mengalami sakit dalam jangka waktu yang lama dan tidak menentu. Secara langsung hal ini tentu saja berpengaruh terhadap stabilitas kondisi emosi anak berambut gimbal.

Di sisi lain, akibat sakit yang dideritanya, anak berambut gimbal gimbal kerap mendapatkan lebih banyak perhatian dari orang-orang di sekitarnya terutama orangtua dan keluarga. Melihat kondisi anak yang memprihatinkan, orangtua berusaha untuk memberikan apapun yang anak inginkan. Anak berambut gimbal memang kerap dimanja selama mereka sakit pada masa awal tumbuhnya rambut gimbal. Lama sakit yang diderita, membuat anak mulai terbiasa dengan perhatian lebih yang mereka dapatkan yang kemudian berdampak pada munculnya perilaku-perilaku "nakal" pasca tumbuhnya rambut gimbal.

Hurlock(1978) menyatakan bahwabanyak anak terbiasa dengan perhatian berlebihan selama dia sakit di mana hal ini menyebabkan anak menjadi agresif dan bânyaik menuntut. Gunarsa (2009) juga 
menyebutkan perilaku "nakal" sebagaimana yang ditunjukkan anak berambut gimbal memang sering diperlihatkan oleh anak-anak yang semasa kecil sering sakit-sakitan. Anak yang sejak masa bayi sering mengalami kejang atau mengalami kenaikan suhu tubuh, tentunya harus diperhatikan dan diawasi agar tidak mengalami perubahan suhu tubuh yang tiba-tiba meninggi. Dengan demikian anak yang sakit kerap mendapat perhatian khusus dan biasanya berbagai keinginannya akan selalu dipenuhi. Lantas, setelah anak sembuh, ia akan memunculkan penyakit lain yakni "cepat meluap kemarahannya" akibat ketidakmampuan menghadapi penolakan terhadap keinginannya karena sudah terbiasa dipenuhi (Gunarsa, 2009; Tasmin, 2002).

Di sisi yang berbeda, paham Kejawen yang terasa kental di masyarakat Dieng yang pada umumnya berprofesi sebagai petani kentang, ditambah dengan latar belakang pendidikan masyarakat yang sebagian besar hanya menempuh pendidikan hingga tingkat sekolah dasar memberikan kontribusi tersendiri terhadap perilakuperilaku anak berambut gimbal. Latar belakang demografi ini secara langsung mempengaruhi munculnya berbagai kepercayaan yang bersifat mitis dan mistis tentang anak berambut gimbal.

Masyarakat percaya bahwa anak berambut gimbal adalah keturunan nenek moyang dataran tinggi Dieng Ki Tumenggung Kaladete. Rambut gimbal itu sendiri menjadi simbol suker yang diberikan pada orangtua maupun anak berambut gimbal. Sebagai titipan Kaladete, masyarakat percaya bahwa di balik wujud rambut gimbal tersebut terdapat mahluk halus yang tidak kasat mata yang menjadi penunggu anak berambut gimbal. Oleh karena itu anak berambut gimbal kerap menunjukkan perilaku-perilaku "nakal" yang dianggap sebagai perbuatan sang penunggu rambut gimbal.

Berbagai kepercayaan tentang anak berambut gimbal inilah yang pada akhirnya memunculkan keyakinan akan sebuah konsep pengasuhan anak berambut gimbal. Karena dianggap sebagai titipan dan diyakini dimomongi oleh mahluk halus, maka setiap orangtua dan lingkungan sekitar anak berambut gimbal diharuskan untuk memanjakan dan selalu memberikan apa yang anak mereka inginkan. Orangtua harus bersikap hati-hati dan bersabar dalam merawat anak berambut gimbal dengan alasan kasihan dan kekhawatiran jika tidak diperlakukan dengan baik makatanak akan menjadi sakit dan dapat berujung pada kematian 
Pengasuhan yang diterapkan oleh lingkungan terdekat anak berambut gimbal ini merupakan pengasuhan permisif di mana orangtua ataupun orang dewasa lain di sekitar anak cenderung memberikan kebebasan pada anak seluas mungkin (Baumrind, 1971). Secara spesifik pengasuhan lingkungan terdekat anak berambut gimbal ini digolongkan ke dalam pengasuhan permisif yang bersifat terlalu pemurah (permissive-indulgent parenting).

Maccoby dan Martin (1983) menjelaskan bahwa pada pola ini orangtua kerap terlibat dengan kehidupan anak, namun sedikit sekali menuntut atau mengendalikan mereka. Biasanya orangtua dengan pengasuhan ini akan memanjakan dan mengizinkan anak untuk melakukan apa saja yang mereka inginkan. Dengan kata lain, pada pengasuhan permisif indulgent, orangtua memiliki tuntutan rendah terhadap anak mereka. Akibatnya, anak-anak tidak pernah belajar mengendalikan perilaku mereka dan selalu mengharapkan kemauan mereka dituruti.

Pengasuhan seperti inilah yang membuat anak semakin kuat mengontrolorang-orang disekitarnya.Sikap orangtua dan lingkungan sekitar anak yang selalu memenuhi apa yang diinginkannya, membuat anak berambut gimbal belajar bahwa dengan cara itu mereka akan selalu mendapatkan apa yang mereka inginkan. Oleh karena itu, setiap kali menginginkan sesuatu dan belum dipenuhi, anak berambut gimbal akan menunjukkan kemarahannya dengan menangis dan mengamuk dalam jangka waktu yang cukup lama ataupun melakukan perilaku-perilaku negatif lainnya.

Keberhasilan demi keberhasilan dari setiap aksi tersebut, membuat anak berambut gimbal terus menerus melakukannya hingga menjadi sebuah kebiasaan. Sebagaimana yang dijelaskan oleh Hurlock (1978) bahwa keberhasilan emosi yang memenuhi kebutuhan anak akan mempengaruhi variasi pola emosi. Jika ledakan marah berhasil memenuhi kebutuhan anak akan perhatian dan memberikan apa yang mereka inginkan, mereka tidak hanya akan terus menggunakan perilaku tersebut untuk mencapai tujuan, tetapi juga akan menambah intensitas ledakan marah, sehingga penilaian mereka terhadap ledakan marah akan meningkat sebagai cara untuk mencapai tujuan yang diinginkan. Reaksi emosional yang memuaskan anak akan diulang-ulang dan pada suatu saat akan berkembang menjadi kebiașaan with 
Sebagaimana pula jika ditinjau dari teori belajar sosial, mekanisme khusus yang menyebabkan munculnya perilaku "nakal" anak berambut gimbal ini mengacu pada prinsip umum belajar, yakni instrumental conditioning. Para ahli teori belajar menekankan bahwa sampai tingkat yang cukup jauh, perilaku sebagaimana perilaku "nakal" anak berambut gimbal disebabkan oleh pengasuhan di mana anak melakukan proses-proses belajar (Bandura, 1983). Pada prinsip ini, anak belajar melalui hadiah dan hukuman. Sejauh mana anak diberi hadiah untuk perilakunya, maka sejauh itu pulalah kemungkinan perilaku yang sama atau serupa akan diperlihatkan lagi di masa yang akan datang (Barbara dan Krahe, 2001).

Hal senada juga disampaikan oleh Gunarsa (2009) yang mengatakan bahwa suatu tingkah laku yang oleh anak dipakai untuk mencapai suatu tujuan dan dianggap berhasil, maka anak akan sering memakai cara yang terbukti itu untuk mencapai tujuannya. Bahkan semakin sering ia berhasil, maka semakin banyak pula permintaannya disertai dengan tingkahlaku yang lebih "meyakinkan" lagi sehingga anak berhasil untuk "menjajah" orangtua yang tidak dapat menolak permintaannya.

Dengan demikian, dapat disimpulkan bahwa berbagai kepercayaan yang dianut oleh sebagian besar masyarakat Dieng terkait dengan anak berambut gimbal telah mempengaruhi pengasuhan yang mereka terapkan terhadap anak berambut gimbal di mana pengasuhan itu sendiri memberikan dampak-dampak tertentu pada perilaku anak berambut gimbal.

Fenomena ini dengan jelas menggambarkan apa yang disampaikan oleh Bronfenbrenner (dalam Berns, 2007) melalui teori ekologikalnya bahwa pengasuhan itu sendiri dipengaruhi oleh lapisan-lapisan sistem sosio-kultural seperti makrosistem yang salah satunya terdapat unsur budaya di dalamnya.

Hal ini juga menunjukkan bahwa pengasuhan bukanlah aktivitas yang bersifat privat (Goodnow, 1990). Dikatakan tidak bersifat privat karena apa yang dilakukan seorang ibu tentu dipengaruhi oleh sang ayah. Begitu pula seterusnya, pengasuhan yang diterapkan orangtua tidak terlepas dari pengaruh orang lain seperti guru, tetangga ataupun keluarga besar bahkan masyarakat di sekitarnya.

Berdasarkan penjelasan di atas, maka disimpulkan bahwa budaya memberikan peengaruh tersendiri dalam pengasuhan 
orangtua terhadap anak-anak mereka, baik itu yang disebabkan oleh pengetahuan, kepercayaan, kebiasaan ataupun tradisi yang berlaku dalam masyarakat tersebut. Dalam konteks ini, latar belakang demografi secara langsung memberi pengaruh terhadap muncul dan berkembangnya berbagai kepercayaan tentang anak berambut gimbal yang pada akhirnya mempengaruhi persepsi dan pengasuhan yang diterapkan oleh para orangtua dan berimplikasi terhadap perilaku anak berambut gimbal itu sendiri.

Selanjutnya, pada masa kanak-kanak awal, perilaku "nakal" yang mereka tunjukkan menjadi semakin meningkat. Munculnya perilaku "nakal" yang merupakan temper tantrum memang sangat terkait dengan masa perkembangan anak pada umumnya yakni pada usia 2-4 tahun, namun demikian, temper tantrum mungkin saja muncul dimulai pada saat anak berusia 8 bulan (Castiglia, 1988). Ada pula yang menyatakan bahwa tantrum kerap muncul pada usia 1 hingga 4 tahun (Belden et al, 2008). Sekitar 75\% anak-anak menunjukkan agresi dan tantrum di usia 2 tahun (Potegal et al., 2003; Tremblay et al., 1999) dan akan mencapai puncaknya $23-80 \%$ pada usia 2-4 tahun (Fetsch dan Jacobson, 1988).

Pada usia ini anak-anak memang kerap menunjukkan berbagai masalah perilaku. Sebagaimana yang diungkapkan oleh Hurlock (1980) bahwa awal masa kanak-kanak yakni pada saat anak berusia dua sampai enam tahun adalah usia yang mengundang masalah atau usia sulit. Pada masa ini, anak-anak sering memunculkan berbagai masalah perilaku yang lebih menyulitkan. Selama awal masa kanakkanak, emosi juga menjadi sangat kuat karena masa ini merupakan saat ketidakseimbangan di mana anak-anak keluar dari fokus yang menyebabkan ia mudah terbawa ledakan-ledakan emosional sehingga sulit dibimbing dan diarahkan (Hurlock, 1980).

Secara umum perkembangan yang dialami oleh anak berambut gimbal dan anak-anak biasa pada umumnya sama saja. Munculnya perilaku "nakal" pada anak biasa maupun anak berambut gimbal memang terjadi pada masa yang sama, yakni masa kanak-kanak awal, akan tetapi karena kondisi kesehatan anak-anak tersebut yang kurang stabil dan adanya berbagai kepercayaan yang diyakini terkait dengan rambut gimbal, membuat mereka mendapat perlakuan yang lebih istimewa dari orangtua maupun lingkungan di sekitarnya dibandingkan dengan anak-anak lain seusianya sehingga anak berambut gimbal menjadi cenderung menupjuken perilaku yang, 
lebih "nakal" dibandingkan dengan anak-anak lainnya di dataran tinggi Dieng.

Pada sisi lainnya, baik orangtua maupun masyarakat telah membuat penilaian tersendiri yang kemudian seakan-akan menjadi kepercayaan tentang anak berambut gimbal. Masyarakat kerap menganggap bahwa anak berambut gimbal adalah anak yang nakal atau rewel. Rambut berbentuk gimbal itulah yang menjadi simbol atas suker yang salah satunya ditunjukkan melalui perilaku-perilaku "nakal" anak berambut gimbal. Anak berambut gimbal diyakini akan selalu menunjukkan perilaku seperti itu hingga rambut gimbalnya dipotong. Masyarakat percaya bahwa ketika rambut gimbalnya sudah dipotong, maka segala sesuatu yang kurang baik yang pada awalnya melekat pada diri anak berambut gimbal, akan hilang dengan sendirinya.

Kepercayaan, persepsi dan simbol inilah yang terakumulasi dan secara sadar ataupun tidak sadar membentuk sebuah sugesti kolektif tentang anak berambut gimbal. Melalui persepsi tersebut, secara serentak masyarakat Dieng sudah memberi label dan menjadikan anak berambut gimbal benar-benar sebagai anak yang nakal.

Fenomena inilah yang disebut sebagai the Pygmalion effect di mana persepsi orangtua, baik yang diucapkan dengan label-label tertentu pada anak, atau yang tidak diucapkan tetapi dicamkan di dalam diri mereka, bisa menjadi kenyataan yang sesungguhnya pada diri anak (Satiadarma, 2001).

Pygmalion effect itu sendiri adalah suatu istilah yang dikemukakan Rosenthal, seorang pakar psikologi yang mengatakan bahwa cara berpikir dan cara pandang seseorang akan menentukan sikap individu tersebut terhadap lingkungannya. Selanjutnya, lingkungannya pun akan memberikan respons atau reaksi sesuai dengan harapan individu yang mempersepsikan. Jadi, ketika orangtua menganggap anaknya nakal dan memberikan label nakal pada anaknya, besar kemungkinan anaknya menjadi nakal (Satiadarma, 2001).

Sejumlah keyakinan sosial masyarakat Dieng cenderung diintroyeksikan ke dalam diri masyarakat tersebut. Artinya, setiap komponen mikrosistem anak berambut gimbal mengambil kepercayaan-kepercayaan zang ada di masyarakat untuk kemudian menjadi landasan persenci mereka. Hal terseput yang kemudian 
digunakan dalam bentuk hipotesa yang bersifat deduktif yang dikenal dengan conceptually driven processes of perception (Satiadarma, 2001). Artinya konsep awal inilah yang digunakan untuk menilai dan berkeyakinan atas suatu hal kemudian.

Jika konsep yang muncul di masyarakat Dieng termasuk orangtua anak berambut gimbal memberi penilaian bahwa rambut gimbal adalah suker dan suker membuat anak berambut gimbal nakal, dengan demikian semua anak berambut gimbal akan nakal. Lantas, ketika melihat tanda-tanda bahwa seorang anak akan berambut gimbal, maka muncul penilaian bahwa anak tersebut kelak ketika sudah benar-benar berambut gimbal akan menjadi anak nakal.

Hal ini didasari oleh skema yang sudah membentuk pemikiran bahwa ketika seorang anak sakit-sakitan dan ternyata sakit yang diderita disebabkan anak akan berambut gimbal, dan memang benar berambut gimbal lantas dapat dipastikan bahwa anak tersebut nantinya akan menjadi anak nakal.

Berdasarkan penjelasan di atas, dapat disimpulkan bahwa penyebab munculnya perilaku "nakal" pada anak berambut gimbal bukanlah semata-mata disebabkan oleh rambut gimbal dengan berbagai cerita mitis dan mistis sebagaimana yang diyakini oleh sebagian besar masyarakat dataran tinggi Dieng. Namun demikian, terdapat berbagai hal yang sifatnya saling pengaruh-mempengaruhi antara faktor satu dengan yang lainnya sehingga memunculkan perilaku "nakal" pada anak berambut gimbal.

\section{Penyebab Perubahan Perilaku Anak Berambut Gimbal Pasca Ruwatan}

Penyebab perubahan perilaku anak berambut gimbal pasca ruwatan juga dikarenakan oleh dua faktor utama yang bersifat interdependen, yakni faktor internal dan faktor eksternal. Faktor internal adalah usia dan kondisi kesehatan. Adapun faktor eksternal terdiri dari kepercayaan terhadap tradisi ruwatan, prosesi ruwatan, pengasuhan dan latar belakang demografi.

Sebagaimana penjelasan dalam penyebab munculnya perilaku "nakal", latar belakang demografi tetap menjadi sesuatu yang berperan memberi kontribusi secara tidak langsung terhadap perubahan perilaku pasca, ruwatan berkaitan dengan berkembangnya kepercayaan-kepercayaan tentang rambut gimbal.maupun tentang . 
tradisi ruwatan. Latar belakang demografi ini secara langsung mempengaruhi apa yang dipikirkan masyarakat mengenai perilaku "nakal" atau sosok anak berambut gimbal itu sendiri. Hal ini dapat dilihat dari bagaimana masyarakat mengkomunikasikan berbagai hal tentang anak berambut gimbal.

Secara kolektif masyarakat memiliki beberapa kepercayaan tentang anak berambut gimbal. Rambut gimbal dijadikan simbol atas suker yang menimpa anak berambut gimbal dan orangtuanya. Masyarakat percaya bahwa berbagai perilaku dan peristiwa yang menimpa anak berambut gimbal dan keluarganya merupakan wujud konkrit dari suker yang diberikan kepada anak berambut gimbal.

Masyarakat juga meyakini bahwa di balik wujud rambut gimbal tersebut terdapat mahluk halus penunggu rambut gimbal yang menjadi penyebab munculnya perilaku "nakal". Oleh karena itu, ketika rambut gimbal tersebut dicukur atau dipotong, maka secara tidak langsung segala sesuatu yang dianggap sebagai kesialan pada anak berambut gimbal akan hilang bersamaan dengan dipenuhinya permintaan sang penunggu melalui permintaan anak berambut gimbal pada saat pelaksanaan ruwatan pemotongan rambut gimbal.

Masyarakat percaya bahwa penunggu yang menjadi penyebab munculnya perilaku-perilaku "nakal" pada anak berambut gimbal pergi bersamaan dengan potongan rambut gimbal yang dilarungkan ke pantai selatan. Lantas, pasca ruwatan anak berambut gimbal akan berubah kembali seperti anak-anak biasa lainnya.

Persepsi positif masyarakat terhadap kepercayaan ini yang diwujudkan dengan sikap mempercayai, secara kolektif dan sugestif memberi pengaruh langsung terhadap perubahan perilaku anak berambut gimbal. Secara serentak masyarakat membuat suatu keyakinan bahwa pasca ruwatan anak berambut gimbal akan membuang segala perilaku negatifnya dan kembali menjadi anak biasa pada umumnya.

Proses ini terjadi sebagaimana the Pygmalion effect yang telah dijelaskan sebelumnya bahwa ketika orangtua mempersepsikan anak berambut gimbal sebagai anak yang baik pasca ruwatan, maka kecenderungan yang lebih besar akan terjadi adalah bahwa anak tersebut akan benar-benar menjadi baik sebagaimana yang

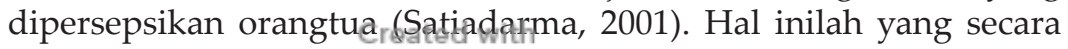
langsung akan membuat anak berambut pimbal melihat dirinyạ 
sebagai diri yang baru, diri yang sudah terbebas dari berbagai macam suker yang dengan demikian perilaku-perilaku "nakal" yang kerap dilakukannya mau tidak mau harus segera dihilangkan.

Di sisi lainnya, ketika masyarakat meyakini bahwa perilaku "nakal" anak berambut gimbal disebabkan oleh mahluk halus penunggu rambut gimbal, maka secara otomatis, upaya penyembuhan yang dipilih dan diyakini dapat menyembuhkan adalah pengobatan tradisional yang bersifat mitis dan mistis pula agar proses pembuangan suker yang juga bersifat mitis dan mistis tersebut dapat berjalan dengan semestinya. Ruwatan dianggap sebagai media yang dapat dan harus dilakukan untuk membuang suker atau penyakit yang mengitari anak berambut gimbal. Melalui ruwatan di mana proses pemotongan rambut gimbal dilakukan, masyarakat percaya bahwa berbagai hal di balik wujud rambut gimbal yang berada di luar wilayah kekuasaan manusia dapat diselesaikan.

Dengan kata lain, ruwatan menjadi mutlak bagi siapapun yang ingin memotong rambut gimbalnya. Tujuannya agar setelah dipotong rambut gimbalnya melalui prosesi ini, anak berambut gimbal akan kembali sehat dan selamat dalam menjalani kehidupannya di masa yang akan datang. Ruwatan itu sendiri dianggap menjadi sesuatu yang sakral dan oleh karenanya hal tersebut tidak dapat dilakukan sembarangan.

Prosesi ruwatan itu sendiri juga berfungsi sebagai media yang turut berkontribusi pada perubahan perilaku anak berambut gimbal. Dalam bahasa Jawa "ruwatan" berasal dari suku kata "ruwat" yang berarti lepas dari kutukan (Suratno, Setiyanto, \& Jatirahayu, 2004). Dengan demikian, ruwatan dapat diartikan sebagai proses pelepasan kutukan yang dalam kasus ini adalah kutukan yang diberikan kepada anak berambut gimbal. Berdasarkan istilahnya saja, ruwatan sudah mengandung unsur sugestif yang cukup besar.

Sebagaimana terapi-terapi tradisional lainnya yang diakui manjur dan efektif bagi masyarakat budaya tertentu untuk sebuah penyembuhan, ruwatan juga dianggap memiliki kemampuan intervensi yang sama. Dalam kasus ini, ada dua hal yang mendasari efektivitas dan kemanjuran terapi-terapi tradisional, termasuk ruwatan yakni kepercayaan dan kekuatan simbol (Levi-Strauss, 1997).

\section{Created with


Kemanjuran ruwatan itu sendiri tidak bisa dijelaskan oleh suatu daya otomatis yang melekat pada tindakan pemangku adat maupun kyai atau rambut gimbal itu sendiri, tetapi pada dasarnya bergantung pada soal "kepercayaan" terhadap hal-hal mistis yang mengelilingi anak berambut gimbal. Sikap kepercayaan ini meliputi tiga unsur yang saling berkaitan (Levi-Strauss, 1997): (1) kepercayaan pemangku adat ataupun kyai terhadap efektivitas seluruh prosedur ruwatan yang dijalankannya, (2) kepercayaan anak berambut gimbal pada kekuatan sang pemangku adat ataupun kyai, (3) kepercayaan, harapan, dan tuntutan masyarakat di mana hubungan antara anak berambut gimbal dan sang pemangku adat ataupun kyai terjalin.

Jadi, masalah utama berkaitan dengan upaya pemangku adat ataupun kyai membebaskan anak berambut gimbal dari berbagai suker yang mengelilinganya terletak pada sifat hubungan kepercayaan antara pemangku adat atau kyai dan anak berambut gimbal dalam konsensus dan kepastian kognitif kolektif masyarakat Dieng.

Dalam konteks ruwatan, pemangku adat atau kyai bertindak sebagai seorang "terapis" yang aktif. Ia membacakan doa-doa tertentu pada saat pemotongan rambut gimbal yang didengar oleh anak berambut gimbal dan masyarakat, lantas diikuti dengan pemotongan rambut gimbal itu sendiri yang keesokan harinya akan dilarungkan ke sungai yang mengalir ke pantai selatan.

Peristiwa pada saat pemangku adat ataupun kyai membacakan doa, memotong rambut gimbal dan memasukkannya ke dalam air bunga, menaburkan beras kuning, hingga melarungkan rambut gimbal ke pantai selatan menjadi serangkaian upaya yang sudah dilakukan untuk membuang suker dari anak berambut gimbal. Kemudian karena masyarakat percaya pada sistem simbolis yang secara mistis mampu menjelaskan fenomena tersebut, maka anak berambut gimbal dan masyarakat dibantu untuk mamahami esensi tradisi ruwatan yang pada akhirnya menimbulkan sebuah kepercayaan. Percaya bahwa dengan melakukan ritual tersebut, segala penyakit dan gangguan telah berakhir dan hal inilah yang menyebabkan pembebasan suker itu terjadi, sebab akhirnya semua kembali pada tempatnya. Rambut gimbal yang merupakan titipan sudah dikembalikan kembali kepada pemiliknya di pantai selatan.

Levi-Strauss (1997) menyatakan bahwa munculnya kepercayaan tersebut disebabkanitbleh adanya "manipulasi simbolis". 
Dieng adalah salah satu kawasan di Indonesia yang masih sangat menjunjung tinggi simbol-simbol. Hal ini dapat dilihat dari berbagai perlengkapan ruwatan yang memiliki makna-makna tertentu di balik benda yang menjadi simbol tersebut. Dalam terapi tradisional seperti ruwatan, materi-materi yang digunakan seperti air bunga, beras kuning, sesajen, payung, kain kafan dan lain sebagainya yang merupakan simbol-simbol tertentu inilah yang justru secara sugestif membantu proses perubahan perilaku pada diri anak berambut gimbal.

Adapun sugesti kolektif yang muncul sebenarnya disebabkan oleh reorganisasi kognitif yang tercipta pada saat prosesi ruwatan berlangsung di mana pengalaman anak berambut gimbal dikaitkan dengan cerita mitos kolektif yang diyakini oleh masyarakat setempat. Hal inilah yang pada tingkatan ketidaksadaran telah mendorong sebuah perubahan perilaku pada diri anak berambut gimbal.

Peran ruwatan sebagai sebuah ritual untuk membuang rambut gimbal menjadi titik awal di mana orangtua anak berambut gimbal \& masyarakat memunculkan sebuah keyakinan baru tentang anak berambut gimbal itu sendiri. Jika awalnya rambut gimbal dianggap sebagai penyebab berbagai perilaku negatif pada anak berambut gimbal, maka dengan dipotong dan dilarungkannya rambut gimbal sebagai simbol atas suker yang selama ini mengitari anak berambut gimbal, perilaku-perilaku negatif itu pun akan hilang bersamaan dengan dikembalikannya rambut gimbal di sungai besar yang mengalir ke pantai selatan.

Keyakinan ini pulalah yang pada akhirnya mempengaruhi pengasuhan yang diterapkan oleh orangtua maupun masyarakat sekitar terhadap anak yang sudah tidak lagi berambut gimbal. Melalui proses ruwatan yang mereka dengar, lihat, ataupun alami sedikit banyak memberi pengaruh terhadap pengasuhan yang mereka praktekkan. Dengan keyakinan bahwa pasca ruwatan, anak akan berubah dan menjadi anak biasa kembali, maka permisivitas yang sebelumnya diterapkan kini mulai berkurang. Kekhawatiran akan munculnya penyakit yang dapat berujung kematian ketika anak berambut gimbal tidak diperlakukan dengan sebaik-baiknya juga sudah tidak lagi mengganggu pikiran orangtua maupun orang dewasa lainnya di sekitar anak berambut gimbal karena saat ini rambut gimbalnya sudah dibuang th $_{\text {A }}$ rinya, tidak ada lagi suker yang akan menimpa anak-anak mereka yang dulußy3 perambut gimbal. 
Di sisi lain, secara internal usia memang mempengaruhi perubahan perilaku. Berbagai perilaku seperti menangis ataupun mengamuk sebagai wujud dari ledakan kemarahan secara normal menurun dengan bertambahnya usia. Reaksi ledakan marah pada anak mencapai puncaknya pada usia antara 2 dan 4 tahun, kemudian diganti dengan pola ekspresi kemarahan yang lebih matang (Hurlock, 1978).

Berdasarkan usia, prevalensi tantrum meningkat dari $87 \%$ pada usia 18-24 bulan menjadi 91\% pada usia 30-36 bulan, kemudian menurun menjadi 59\% pada usia 42-48 bulan (Potegal \& Davidson, 2003). Hal senada juga disampaikan oleh Gunarsa (2009) yang menyatakan bahwa gejala tantrum biasanya akan hilang ketika anak berusia 4-6 tahun.

Kesehatan yang mulai stabil juga memberi pengaruh pada munculnya emosi yang menyenangkan menjadi dominan dalam diri anak. Selain itu pula, secara fisik kepala anak menjadi lebih ringan dan bersih karena sudah tidak lagi terbebani dengan rambut gimbal yang berat, terkadang kotor dan banyak kutunya. Dengan demikian setelah tidak lagi berambut gimbal anak merasa lebih senang dibandingkan ketika masih berambut gimbal dan menunjukkan perilaku-perilaku yang lebih positif serta tidak lagi menunjukkan berbagai perilaku "nakal"nya pasca pemotongan rambut gimbal.

Subjek 4, AAF adalah sebuah pengecualian dalam kasus ini. Meskipun sudah memotong rambut gimbalnya, AAF tidak menunjukkan perubahan signifikan sebagaimana ketiga subjek lainnya. AAF sudah melakukan pemotongan rambut gimbal, namun demikian ia belum berkesempatan untuk mengadakan prosesi ruwatan. Oleh karena itu, rambut gimbal yang sudah dipotong hanya disimpan dalam sebuah toples yang baru akan dilarungkan ke pantai selatan ketika AAF mengadakan tradisi ruwatan.

Dalam budaya Dieng, masyarakat percaya bahwa ketika prosesi ruwatan belum diadakan maka perilaku anak berambut gimbal juga belum akan berubah sepenuhnya. Asumsinya bahwa rambut gimbal yang menjadi titipan itu belum dikembalikan sehingga anak berambut gimbal masih dianggap belum bebas secara total dari suker yang ditanggungnya. Berdasarkan keyakinan ini pula, maka pengasuhan yang diterapkan oleh orangtua maupun lingkungan sekitar AAF juga masih tampak sama sebagaimana ketika AAF berambut gimbal. Oleh karena itu AAF masih menunjukkan perilaku-perilaku "nakal"nya. 
Fenomena ini secara langsung menunjukkan betapa sugesti kolektif yang dibangun masyarakat terkait dengan sakralisasi ruwatan telah memberikan pengaruh yang signifikan terhadap persepsi yang berdampak pada pengasuhan orangtua maupun masyarakat sekitarnya yang kemudian mempengaruhi perilaku anak berambut gimbal. Meskipun demikian, sangat memungkinkan terdapat faktor penyebab lainnya yang juga berkontribusi terhadap perilaku AAF yang belum banyak menunjukkan perubahan pasca pemotongan rambut gimbal.

\section{Kesimpulan}

Hasil analisis data dan pembahasan menyimpulkan bahwa perilaku "nakal" anak berambut gimbal merupakan temper tantrum yakni luapan emosi yang meledak-ledak dan tidak terkontrol, disertai rasa marah, serangan agresif, menangis, menjerit-jerit ketika apa yang mereka inginkan tidak segera dipenuhi. Berdasarkan hasil penelitian ini terdapat beberapa faktor yang saling mempengaruhi munculnya perilaku "nakal" pada anak berambut gimbal. Faktor-faktor tersebut secara umum diklasifikasikan menjadi dua faktor utama yakni faktor internal dan eksternal. Faktor internal terdiri dari usia dan kondisi kesehatan fisik anak berambut gimbal. Adapun faktor eksternal terdiri dari pengasuhan, sugesti kolektif, kepercayaan tentang anak rambut gimbal, persepsi terhadap kepercayaan tentang anak berambut gimbal dan latar belakang demografi.

Kondisi kesehatan yang begitu labil yang mereka alami sejak awal munculnya rambut gimbal menimbulkan kondisi emosi yang tidak menyenangkan menjadi dominan dalam diri anak dan berdampak pada munculnya cikal bakal perilaku "nakal" anak berambut gimbal. Ketidakstabilan kesehatan anak berambut gimbal juga berimplikasi pada pengasuhan orangtua yang bersifat permisif. Melihat kondisi anak yang memprihatinkan, orangtua berusaha untuk memberikan apapun yang anak inginkan.

Selain karena kondisi kesehatan anak, permisifnya pengasuhan orangtua maupun lingkungan terdekat anak berambut gimbal juga dipengaruhi oleh berbagai kepercayaan yang bersifat mitis dan mistis tentang keberadaaan anak berambut gimbal. Karena diyakini sebagai keturunan Kaladete dan dimomongi oleh mahluk halus, maka orangtua dan masyarakat setempat memunculkan keyakinan akan sebuah konsep penrasuhan anak beжsplut gimbal Setiap. 
orangtua anak berambut gimbal diharuskan untuk memanjakan dan selalu memberikan apa yang anak mereka inginkan. Orangtua harus bersikap hati-hati dan bersabar dalam merawat anak berambut gimbal dengan alasan kasihan dan kekhawatiran jika tidak diperlakukan dengan baik maka anak akan menjadi sakit dan dapat berujung pada kematian. Akibatnya, anak-anak berambut gimbal tidak pernah belajar mengendalikan perilaku mereka dan selalu mengharapkan kemauan mereka dituruti.

Di sisi lain, faktor usia juga mempengaruhi perilaku anak berambut gimbal. Munculnya perilaku "nakal" yang merupakan temper tantrum memang sangat terkait dengan masa perkembangan anak yakni pada usia 2-4 tahun. Selain itu pula, anak berambut gimbal adalah anak-anak yang berada di masa kanak-kanak awal yang memang dikenal sebagai usia yang mengundang masalah atau usia sulit.

Secara umum perkembangan yang dialami oleh anak berambut gimbal dan anak-anak biasa pada umumnya sama saja. Munculnya perilaku "nakal" pada anak biasa maupun anak berambut gimbal memang terjadi pada masa yang sama, akan tetapi karena adanya rambut gimbal yang tumbuh di kepala mereka, membuat anak-anak ini mendapat perlakuan yang lebih istimewa dari orangtua maupun lingkungan di sekitarnya dibandingkan dengan anak-anak lain seusianya. Hal inilah yang kemudian berperan menjadikan anak berambut gimbal cenderung lebih "nakal" dari anak-anak biasa lainnya di dataran tinggi Dieng.

Selain itu, latar belakang demografi juga turut mempengaruhi munculnya perilaku "nakal" anak berambut gimbal. Budaya di mana masyarakat Dieng masih memegang teguh paham Kejawen disertai dengan latar pendidikan yang sebagian besar merupakan lulusan Sekolah Dasar telah memunculkan berbagai kepercayaan yang bersifat mitis dan mistis tentang keberadaaan anak berambut gimbal yang kemudian dipersepsi dengan sikap mempercayai. Keyakinankeyakinan inilah yang memunculkan sugesti kolektif bahwa anak berambut gimbal dianggap sebagai anak yang nakal dan pada akhirnya benar-benar menjadi anak yang "nakal".

Tidak berbeda halnya dengan perubahan perilaku pasca pemotongan rambut gimbal. Penyebab perubahan perilaku anak berambut gimbal pasca reated taith juga dikarenakan oleh dua faktor

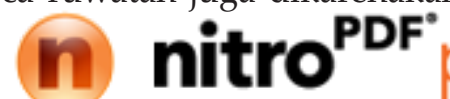


utama yang bersifat interdependen, yakni faktor internal dan faktor eksternal. Faktor internal adalah usia dan kondisi kesehatan. Adapun faktor eksternal terdiri dari kepercayaan terhadap tradisi ruwatan, prosesi ruwatan, pengasuhan dan latar belakang demografi.

Sebagaimana penyebab munculnya perilaku "nakal", penyebab perubahan perilaku anak berambut gimbal juga sangat dipengaruhi oleh latar belakang demografi yang berdampak pada munculnya berbagai kepercayaan tentang tradisi ruwatan yang dianggap sebagai media ampuh untuk menghilangkan perilaku "nakal" anak berambut gimbal.

Ruwatan sebagai sebuah ritual untuk membuang rambut gimbal menjadi titik awal di mana orangtua anak berambut gimbal \& masyarakat memunculkan sebuah keyakinan baru tentang anak berambut gimbal. Jika awalnya rambut gimbal dianggap sebagai penyebab berbagai perilaku negatif pada anak berambut gimbal, maka dengan dipotong dan dilarungkannya rambut gimbal sebagai simbol atas suker yang selama ini mengitari anak berambut gimbal, perilaku-perilaku negatif itu pun akan hilang bersamaan dengan dikembalikannya rambut gimbal di sungai besar yang mengalir ke pantai selatan.

Keyakinan ini pulalah yang pada akhirnya mempengaruhi pengasuhan yang diterapkan oleh orangtua maupun masyarakat sekitar terhadap anak yang sudah tidak lagi berambut gimbal. Dengan keyakinan bahwa pasca ruwatan anak akan berubah dan menjadi anak biasa kembali, maka permisivitas yang sebelumnya diterapkan kini mulai berkurang. Kekhawatiran akan munculnya penyakit yang dapat berujung kematian ketika anak berambut gimbal tidak diperlakukan dengan sebaik-baiknya juga sudah tidak lagi mengganggu pikiran orangtua maupun orang dewasa lainnya di sekitar anak berambut gimbal karena saat ini rambut gimbalnya sudah dibuang. Artinya, tidak ada lagi suker yang akan menimpa anak-anak mereka yang dulunya berambut gimbal.

Dengan demikian, lingkungan terdekat anak berambut gimbal secara otomatis akan menerapkan praktek pengasuhan yang berbeda sebagaimana saat anak masih berambut gimbal. Jika pada saat anak masih berambut gimbal segala sesuatunya akan segera dipenuhi, maka pasca ruwatan, tidak semua yang diinginkan anak berambut gimbal akan dituruti. Perabahan pengasuhan yang terjadi secara 
serentak oleh semua mikrosistem, secara eksternal memberikan pengaruh yang cukup signifikan terhadap perubahan perilaku anak.

Selain itu pula, keyakinan-keyakinan yang dipercayai masyarakat terkait dengan anak gimbal pasca ruwatan, secara kolektif dan sugestif memberi pengaruh langsung terhadap perubahan perilaku anak berambut gimbal. Secara serentak masyarakat membuat suatu keyakinan bahwa pasca ruwatan anak berambut gimbal akan membuang segala perilaku negatifnya dan kembali menjadi anak biasa pada umumnya.

Hal inilah yang secara langsung akan membuat anak berambut gimbal melihat dirinya pasca prosesi ruwatan sebagai diri yang baru, diri yang sudah terbebas dari berbagai macam suker yang dengan demikian perilaku-perilaku "nakal" yang kerap dilakukannya mau tidak mau harus segera dihilangkan.

Di samping itu, usia pada saat rata-rata anak melakukan pemotongan rambut gimbal merupakan masa di mana perilaku "nakal" anak akan berangsur-angsur berubah menjadi lebih baik. Di sisi lain, kesehatan yang mulai stabil juga memberi pengaruh pada munculnya emosi yang menyenangkan menjadi dominan dalam diri anak. Selain itu pula, secara fisik kepala anak menjadi lebih ringan dan bersih karena sudah tidak lagi terbebani dengan rambut gimbal yang berat, terkadang kotor dan banyak kutunya. Dengan demikian setelah tidak lagi berambut gimbal anak merasa lebih senang dibandingkan ketika masih berambut gimbal dan menunjukkan perilaku-perilaku yang lebih positif.

Dari hasil penelitian tersebut, peneliti menyarankan:

Berdasarkan hasil penelitian, dalam kasus-kasus tertentu pada penelitian-penelitian maupun kajian kelimuan lainnya, kiranya faktor sosio-kultural seperti budaya, adat-istiadat, keyakinan dan hal-hal lain yang melekat dalam diri setiap masyarakat dalam komunitas tertentu sekiranya dapat dijadikan salah satu aspek yang harus selalu diperhatikan ketika membahas berbagai masalah perkembangan. Karena bagaimanapunjuga lingkungan di mana seorang anak tumbuh dan dibesarkan tentu akan memberi pengaruh-pengaruh tertentu seperti cara pandang orangtua terhadap anak atau pengasuhan, yang mana hal-hal tersebut tentu saja akan mempengaruhi proses perkembangan anak. Created with 
Berdasarkan proses penelitian yang sudah peneliti lakukan, bagi peneliti yang akan datang kiranya perlu mempersiapkan penelitian lapangan ini dengan sebaik mungkin, terutama berkaitan dengan kualitas peneliti sebagai instrumen utama penelitian. Peneliti harus tahu benar bagaimana cara untuk membangun rapport yang baik dengan calon responden dan informan karena hal tersebut akan sangat mempengaruhi data penelitian. Begitu pula halnya dalam upaya mengumpulkan data. Keterampilan wawancara juga harus dipersiapkan mengingat berbagai karakteristik responden dan informan yang sangat beragam. Berkaitan dengan tema penelitian, kiranya penelitian ini dapat diteliti melalui penelitian longitudinal sehingga dapat diketahui secara detail faktor-faktor yang mempengaruhi muncul dan berkurangnya perilaku "nakal" padaanak berambut gimbal, kapan setiap faktor tersebut mulai berkontribusi dan seberapa besar pengaruh setiap faktor tersebut. Selain itu pula, kiranya perlu dilakukan penelitian-penelitian perkembangan dengan berbagai tema yang lain, baik itu yang berhubungan dengan anak berambut gimbal ataupun masalah perkembangan lainnya di masyarakat umum di dataran tinggi Dieng.

\section{Daftar Pustaka}

Barbara \& Krahe. (2005). Perilaku agresif: buku panduan psikologi sosial. Jogjakarta: Pustaka Pelajar.

Berns, R.M. (2007). Child, family, school, community, social support. Canada: Thomson Wadsworth.

Bestarini, A. E. (2009). Pengaruh modernisasi terhadap pelestarian tradisi upacara ruwatan cukur rambut gembel di Desa Sendangsari, Kecamatan Garung, Kabupaten Wonosobo. Skripsi. Program Studi Pendidikan Sosiologi Jurusan Pendidikan Sejarah Fakultas Ilmu Sosial \& Ekonomi Universitas Negeri Yogyakarta. Baumrind, D. (1971). Current, patterns of parental authority. Development Psychology Monograph 4, No. 1

Belden, A. C., Thomson N. R., Luby J. L. (2008). Temper tantrums in healthy versus depressed and disruptive preschoolers: defining tantrum behaviors associated with clinical problems. The Journal of Pediatrics, Vol. 151:6.

Buehler, C \& Gerard, J. M. (2002). Marital conflict, ineffective parenting, and children's and adolescents' maladjustment. Journal of Marriage and Family 64: 78-92.

Castiglia, P. T. (1988). Temnar tantrums. Grozpthoud Development 2, 5. 
Chaplin, J. P. (2006). Kamus lengkap psikologi. Jakarta: Raja Grafindo Persada.

Conger, R. D., Conger, K. J., Elder, G. H., Jr., Lorenz, F. O., Simons, R. L., \& Whitbeck, L. B. (1992). A family process model of economic hardship and adjustment of early adolescent boys. Child Development, 63, 526-541.

Cummings, E. M \& Davies, P. T. (1994). Maternal depression and child development. Journal of Child Psychology and Psychiatry 35 (1), 73-112.

Curtner-Smith, M. E. (2000). Mechanisms by which family processes contribute to school-age boys' bullying. Child Study Journal, 30, 169-186.

Ellis, W. E \& Zarbatany, L. (2007). Peer group status as a moderator of group influence on children's deviant, aggressive, and prosocial behavior. Child Development, 78 (4), 1240-1254.

Emery, R. E \& Waldron, M., Kitzmann, K. M. \& Aaron, J. (1999). Delinquent behavior, future divorce or nonmarital childbearing, and externalizing behavior among offspring: a 14-year prospective study. Journal of Family Psychology, 13 (4), 568-579.

Fetsch \& Jacobson B. (1996). Children's anger and temper tantrums. Family Consumer Series, No. 10.248.

Flouri, E., \& Buchanan,A. (2003). The role of mother involvement and father involvement in adolescent bullying behavior. Journal of Interpersonal Violence, 18, 634-644.

Georgiades, K., Boyle, M. H., \& Duku, E. (2007). Contextual influences on children's mental health and school performance: The moderating effects of family immigrant status. Child Development, 78 (5), 1572-1591.

Goodnow, J. J (1990). The socialization of cognition. In J. W. Stigler, R. A. Shweder, \& G. Herdt (Eds.). Cultural psychology: Essays on comparative human development. Cambridge, England: Cambridge University Press.

Gunarsa, S. D. (2009). Psikologi anak bermasalah. Jakarta: Gunung Mulia.

Hart, H., Box, M., \& Jenkins, S. (1984). Health and behavior in preschool children. Child: Care, Health and Development, 10, l-16. 
Hill, A. L., Degnan, K. A., Calkins, S. D. \& Keane, S. P. (2006). Profiles of externalizing behavior problems for boys and girls across preschool: the roles of emotion regulation and inattention. Developmental Psychology, 42 (5), 913-928.

Hurlock, E. B. (1978). Child development (6 $6^{\text {th }}$ edition). USA : McGrawHill, Inc.

Hurlock, E.B. (1980). A life-span approach, (5 ${ }^{\text {th }}$ edition). USA : McGrawHill, Inc.

Jouriles, E. N., Pfiffner, L. J., \& O’Leary, S. G. (1988). Marital conflict, parenting and toodler conduct problems. Journal of Abnormal Child Psychology, 16 (2), 197-206.

Kaczynski, K. J., Lindahl, K. M., Malik, N. M., \& Laurenceau, J. (2006). Marital conflict, maternal and paternal parenting, and child adjustment: A test of mediation and moderation. Journal of Family Psychology, 20, 199-208.

Levi-Strauss, C. (1997). Mitos, dukun, dan sihir. Terjemahan: Drs. Agus Cremers, SVD dan Drs. De Santo Johanes. Yogyakarta: Kanisius.

Maccoby, E. E., \& Martin, J. A. (1983). Handbook of child psychology: Vol. 4. New York: Wiley

McCoy, M. G., Frick, P. J., Loney, B. R., \& Ellis, M. L. (1999). The potential mediating role of parenting practices in the development of conduct problems in a clinic-referred sample. Journal of Child and Family Studies, 8, 477-494.

Miller, N. B., Cowan, P. A., Cowan, C. P., Hetherington, E. M., \& Clingempeel, W. G. (1993). Externalizing in preschoolers and early adolescents: A cross-study replication of a family model. Developmental Psychology, 29, 3-18.

Mrug, S. \& Windle , M. (2009). Mediators of neighborhood influences on externalizing behavior in preadolescent children. Journal of Abnormal Child Psychology 37:265-280.

Nagin, D., \& Tremblay, R. E. (1999). Trajectories of boys' physical aggression, opposition, and hyperactivity on the path to physically violent and nonviolent juvenile delinquency. Child Development, 70 (5), 1181-1196.

O'Leary, S. G \& Vidair, H. B. (2005). Marital adjustment, child-rearing disagreements, and overreactive parenting: Predicting child behavior problems. đoorthal of iffamily Psychology, 19 (2), 208-216. 
Potegal, M., \& Davidson, R. J. (2003). Temper tantrums in young children: Behavioral composition. Developmenta andBehavioral Pediatrics,24,140-147.

Potegal, M., Kosorok, M., \& Davidson, R. (2003). Temper tantrums in young children: Tantrum duration and temporal organization. Journal of Developmental and Behavioral Pediatrics, 24, 148-154.

Purwadi (2003). Kamus Jawa-Indonesia. Yogyakarta: Penerbit Widyatama.

Rambey, A. (2009). Anggrung gondok dan rambut gimbal. http://regional. kompas.com/read/2009/08/30/10572132/foto.anggrung.gondok. dan.rambut.gimbal. Diunduh pada tanggal 19 Januari 2010.

Satiadarma, M. P., (2001). Persepsi orangtua membentuk perilaku anak. Jakarta: Pustaka Populer Obor.

Shaw, D. S., Gilliom, M., Ingoldsby, E. M. \& Nagin, D. (2003). Trajectories leading to school-age conduct problems. Developmental Psychology, 39, 189-200.

Suratno, P., Setiyanto, E., Jatirahayu, W. (2004). Kamus praktis JawaIndonesia. Yogyakarta: IQ Wacana.

Tavris, C. (1989). Anger: the misunderstood emotion. Ed Revision. New York: Simon and Schuster.

Tremblay, R. E., Nagin, D. S., Seguin, J. R., Zoccolillo, M., Zelazo, P. D., Boivin, M. (2004). Physical aggression during early childhood: Trajectories and predictors. Pediatrics, 114, e43-e50.

Wibowo, H. J. (1969). Anak gembel di Dukuh Tompak. Skripsi. Fakultas Sastra \& Kebudayaan Universitas Gadjah Mada Yogyakarta.

Yulianto. (2009). Ruwatan rambut gimbal.http://suaramerdeka.com/ v1/index.php/re ad/cetak/2009/10/02/82453/Ruwatan.Rambut. Gimbal. Diunduh pada tanggal 19 Januari 2010.

\section{Created with}

